\title{
PENGARUH PEMBERIAN KOMBINASI MINYAK RAMI DENGAN MINYAK WIJEN TERHADAP KADAR KOLESTEROL HIGH DENSITY LIPOPROTEIN (HDL) TIKUS SPRAGUE DAWLEY DISLIPIDEMIA
}

\author{
Bike Meisyahputri, Martha Ardiaria*)
}

Program Studi Ilmu Gizi Fakultas Kedokteran Universitas Diponegoro

Jln. Prof. H. Soedarto, SH., Semarang, Telp (024) 8453708, Email : gizifk@ undip.ac.id

\begin{abstract}
Background: Dyslipidemia is the risk factor of cardiovascular diseases (CVD) such as coronary heart diseases (CHD) and artherosclerosis. Dyslipidemia is a lipid metabolism disorder, one of it is a decreased High Density Lipoprotein (HDL) cholesterol level in the blood. Flaxseed and sesame oil contained linolenic acid, linoleic acid and antioxidant have potential effect in increasing HDL cholesterol level in the blood.

Objective: Investigate the effect of flaxseed and sesame oil combination administration on HDL cholesterol level in dyslipidemia Sprague dawley rats.

Methods: A true experimental with pre-post randomized control group design on 24 dyslipidemia Sprague dawley rats which was randomized into 4 groups. The control group was given standard diet and high cholesterol diet and three treatment groups were given high cholesterol diet also flaxseed and sesame oil in combination with the dose of 1ml/200 gr body weight (P1), $2 \mathrm{ml} / 200 \mathrm{gr}$ body weight (P2), and $3 \mathrm{ml} / 200 \mathrm{gr}$ body weight (P3) for 14 days. High Density Lipoprotein (HDL) cholesterol level was analyzed by CHOD-PAP method. Datas were analyzed by Paired t-test and Anova.

Results: There was a significant difference on HDL cholesterol level before and after treatment in control group 1,43\% $(p=0,003)$. Treatment groups $(P 1, P 2, P 3)$ had significant elevation $(p<0,05)$ on HDL cholesterol level respectively $18,49 \%(p=0,000), 29,21 \%(p=0,000)$, and $50,85 \%(p=0,000)$.

Conclusion: Flaxseed and sesame oil combination for 14 days could increase HDL cholesterol level. The most potential effect in increasing HDL cholesterol level was shown in P2 the dose of $3 \mathrm{ml} / 200 \mathrm{gr}$ body weight.
\end{abstract}

Keywords: Flaxseed oil, sesame oil, HDL cholesterol, dyslipidemia

\begin{abstract}
ABSTRAK
Latar Belakang: Dislipidemia merupakan faktor risiko dari penyakit kardiovaskular (CVD) seperti penyakit jantung koroner (PJK) dan artherosklerosis. Dislipidemia adalah kelainan metabolisme lipid dalam darah. Salah satu kelainan komponen lipid yaitu menurunnya kadar kolesterol High Density Lipoprotein (HDL). Minyak rami dan minyak wijen yang mengandung asam linolenat, asam linoleat dan antioksidan yang berpotensi dalam meningkatkan kadar kolesterol HDL darah. Penelitian ini bertujuan untuk mengetahui pengaruh pemberian kombinasi minyak rami dengan minyak wijen terhadap kadar kolesterol HDL pada tikus dislipdemia.

Metode : Penelitian true experimental dengan pre-post test randomized control group design terhadap 24 ekor tikus Sprague dawley dislipidemia dibagi secara acak menjadi 4 kelompok yaitu kelompok kontrol diberikan pakan standar dan tinggi kolesterol dan tiga kelompok perlakuan diberikan pakan tinggi kolesterol dan kombinasi minyak rami dengan minyak wijen dosis $1 \mathrm{ml} / 200 \mathrm{gBB}, 2 \mathrm{ml} / 200 \mathrm{gBB}, 3 \mathrm{ml} / 200 \mathrm{gBB}$ selama 14 hari. Kadar kolesterol HDL diperiksa dengan metode CHOD-PAP. Data dianalisis dengan uji Paired t-test dan Anova.

Hasil : Terdapat perbedaan penurunan kolesterol HDL secara bermakna sebelum dan sesudah perlakuan pada kelompok kontrol sebesar 1,43\% ( $p=0,003)$. Kelompok P1, P2, P3 mengalami peningkatan kolesterol HDL secara bermakna $(p<0,05)$ berturut-turut yaitu sebesar 18,49\% ( $p=0,000), 29,21 \%(p=0,000)$, dan 50,85\% ( $p=0,000)$.

Simpulan : Ketiga kelompok perlakuan dengan pemberian kombinasi minyak rami dengan minyak wijen selama 14 hari terbukti dapat meningkatkan kadar kolesterol HDL. Kelompok perlakuan dosis 3 ml/200 gBB paling efektifmeningkatkan kolesterol HDL pada tikus dislipidemia.
\end{abstract}

Kata kunci: Minyak rami, minyak wijen, kolesterol HDL, dislipidemia

\section{PENDAHULUAN}

Dislipidemia

metabolisme lipid dimana terjadi peningkatan maupun penurunan komponen lipid dalam darah. Kelainan komponen lipid yang terjadi yaitu kenaikan kadar kolesterol total, kolesterol Low Density Lipoprotein (LDL), trigliserida (TG), serta menurunnya kadar kolesterol High Density
Lipoprotein (HDL). ${ }^{1-4}$ Dislipidemia merupakan faktor risiko dari penyakit kardiovaskular (CVD) seperti penyakit jantung koroner (PJK) dan artherosklerosis. ${ }^{1,4}$ Prevalensi dislipidemia di Indonesia semakin meningkat. Berdasarkan Riskesdas 2013, seluruh penduduk usia $\geq 15$ tahun didapatkan kolesterol total abnormal dengan kategori borderline 200-239 mg/dl dan tinggi $>240 \mathrm{mg} / \mathrm{dl}$ 
sebesar 35,9\%, kadar HDL dibawah nilai normal menurut NCEP-ATP III secara keseluruhan didapatkan 22,9\%, kadar LDL diatas nilai normal sebanyak $60,3 \%$ dan kategori tinggi-sangat tinggi $15,9 \%$. Kosentrasi kadar kolesterol total dan kolesterol HDL sering digunakan untuk menilai prevalensi dislipidemia pada populasi. .,6,7 $^{5}$

High Density Lipoprotein sering disebut juga kolesterol baik karena berfungsi membawa kolesterol maupun membuang kelebihan kolesterol jahat dari pembuluh darah arteri kembali ke hati sehingga dapat dimetabolisme lalu dibuang ke dalam kandung empedu sebagai cairan empedu, sehingga penimbunan kolesterol di pembuluh darah arteri berkurang. Kolesterol HDL juga berfungsi mencegah kolesterol mengendap di arteri dan melindungi pembuluh darah dari proses aterosklerosis (terbentuknya plak pada dinding pembuluh darah). ${ }^{8}$ Kadar HDL normal orang dewasa yaitu $45 \mathrm{mg} / \mathrm{dl}$ dan kadar HDL normal pada tikus yaitu $\geq 35 \mathrm{mg} / \mathrm{dl} .{ }^{9}$ Rendahnya kadar kolesterol HDL terkait dengan kejadian penyakit jantung dan stroke. ${ }^{10}$

Faktor risiko yang dapat mempengaruhi kadar kolesterol HDL yaitu asupan makan, aktivitas fisik, genetik, usia, jenis kelamin, dan penyakit. Diet memainkan peran penting dalam pengendalian homeostasis kolesterol. ${ }^{11}$ Penelitian melaporkan minyak nabati kaya akan asam lemak tak jenuh dapat digunakan sebagai makanan dan untuk tujuan pengobatan hiperlipidemia, mengurangi risiko penyakit kardiovaskular dan perubahan dalam metabolisme hati. ${ }^{12}$ Minyak nabati yang tinggi asam lemak tak jenuh diantaranya minyak rami dan minyak wijen. Minyak rami mengandung asam lemak jenuh 9\%, asam lemak tak jenuh rantai tunggal (MUFA) $16 \%$ dan asam lemak tak jenuh rantai ganda (PUFA) $75 \% .{ }^{13}$ Minyak wijen mengandung asam lemak jenuh $14 \%$, asam lemak tak jenuh rantai tunggal (MUFA) $39 \%$ dan asam lemak tak jenuh rantai ganda (PUFA) $46 \% .{ }^{14}$

Minyak rami adalah minyak yang berasal dari biji rami (Linum usitatissimum) memiliki asam lemak $\alpha$ linolenat (omega 3 ) yang tinggi sebesar $57 \%$, asam oleat (omega 9), asam linoleat (omega 6). ${ }^{15,16}$ Minyak rami pada tikus yang diberi diet tinggi kolesterol mengakibatkan penurunan yang signifikan terhadap kolesterol total, LDL, VLDL dan serum trigliserida. ${ }^{17}$ Minyak wijen adalah salah satu minyak nabati yang berasal dari biji wijen (Sesamum indicum L) yang mengandung tinggi asam lemak tak jenuh dan zat antioksidan. Asam lemak yang terkandung didalam minyak wijen yaitu asam oleat, linoleat, linolenat, palmitat dan stearat. Minyak wijen juga mengandung sesamin, sesamol, dan sesamolin yang berperan penting dalam stabilitas oksidatif dan aktivitas antioksidan. ${ }^{18}$ Berdasarkan penelitian Biswas dan
Sedigheh pemberian bubuk biji wijen pada tikus hiperlipidemia secara signifikan dapat menurunkan total lipid pada serum plasma dan hati, kolesterol total dan kolesterol LDL serta dapat meningkatkan konsentrasi HDL. ${ }^{19,20}$

Minyak rami memiliki sifat yang rentan terhadap ketengikan (oksidasi) sehingga memiliki umur simpan yang sangat pendek. Sebaliknya, minyak wijen dikenal paling tahan terhadap ketengikan (oksidasi) diantara minyak nabati lainnya karena mengandung antioksidan alami dan asam oleat yang tinggi. ${ }^{20,21}$ Asam oleat dan antioksidan dapat menghambat oksidatif, meningkatkan kualitas rasa, dan umur simpan yang lebih lama. ${ }^{22}$

Menurut penelitian Goutam, penggunaan minyak biji rami dikombinasikan dengan minyak nabati lain kemungkinan akan dapat meningkatkan kestabilan minyak terhadap oksidatif sehingga meningkatkan efek pada pengendalian dislipidemia yang dikaitkan dengan DM tipe $2 .{ }^{23}$ Minyak rami dan minyak wijen memiliki kandungan asam lemak tak jenuh ganda (omega 3 dan omega 6) yang tinggi dan keduanya memilki sifat kardioprotektif. Kedua minyak tersebut dikenal sebagai salah satu makanan alami yang memiliki efek menguntungkan pada profil lipid darah, mencegah berbagai gangguan kesehatan seperti hipertensi, kanker, hiperkolesterolemia dan penuaan..$^{15,16,18}$

Berdasarkan uraian tersebut, peneliti ingin melakukan penelitian tentang pengaruh pemberian kombinasi minyak rami dengan minyak wijen terhadap kadar kolesterol HDL pada tikus Sprague dawley dislipidemia.

\section{METODE PENELITIAN}

Penelitian ini merupakan penelitian true experimental dengan pre and post test randomized control group design yang dilaksanakan di Laboratorium Pusat Studi Pangan dan Gizi Universitas Gajah Mada, Yogyakarta. Variabel bebas penelitian ini adalah pemberian kombinasi minyak rami dengan minyak wijen dosis $1 \mathrm{ml}, 2 \mathrm{ml}$ dan $3 \mathrm{ml}$ per 200 gBB tikus. Variabel terikat adalah kadar kolesterol HDL.

Subjek penelitian yang digunakan yaitu tikus jantan galur Sprague dawley yang berumur 6-8 minggu dengan berat badan 150-200 gram dalam kondisi sehat (aktif dan tidak cacat) yang diperoleh dari Unit Pengembangan Hewan Percobaan (UPHP) Universitas Gajah Mada. Besar sampel penelitian ditentukan berdasarkan ketentuan WHO, dengan jumlah sampel minimal per kelompok adalah 5 ekor. ${ }^{24}$ Untuk mengantisipasi tikus yang drop out ditambah $10 \%$ pada tiap kelompok. Penelitian ini terdiri dari 4 kelompok dan setiap kelompok terdiri dari 6 ekor tikus, sehingga jumlah tikus yang menjadi 
sampel penelitian yaitu 24 ekor. Pemilihan jenis tikus ini karena tikus Sprague dawley lebih sensitif terhadap lipid dan lebih tahan terhadap perlakuan dibandingkan tikus galur wistar yang pernah dilakukan pada penelitian sebelumnya. ${ }^{25}$ Penggunaan tikus jantan karena memberikan hasil penelitian yang lebih stabil karena tidak dipengaruhi hormon estrogen. ${ }^{26}$

Seluruh sampel diadaptasi selama 7 hari dan diberikan pakan standar sebanyak $20 \mathrm{~g} / 200 \mathrm{gBB}$ tikus. Jenis pakan standar yang digunakan adalah AD II Comfeed yang mengandung air $(\max 12 \%)$, protein kasar (min 15\%), lemak kasar 3-7\%), serat kasar (max 6\%), abu $(\max 7 \%)$, kalsium $(0,9-1,1 \%)$ dan fosfor $(0,6-0,9 \%)$ dan minum aquades secara $a d$ libitum. Setelah masa adaptasi tikus dibagi secara acak dengan metode simple random sampling menjadi 4 kelompok yaitu kelompok kontrol, kelompok perlakuan 1 (P1), perlakuan 2 (P2) dan perlakuan 3 (P3). Keempat kelompok diberi pakan standar, dan pakan tinggi kolesterol selama 14 hari untuk membuat tikus dalam kondisi dislipidemia. Pakan tinggi kolesterol yang diberikan terdiri dari $10 \%$ pakan tinggi lemak bagian perut daging babi serta $2 \%$ asam kolat. Selanjutnya dilakukan pengambilan darah untuk menganalisis kadar kolesterol HDL awal sebelum perlakuan. Tikus dikatakan dislipidemia jika kadar kolesterol total $\geq$ $200 \mathrm{mg} / \mathrm{dl}$, kolesterol LDL $\geq 66 \mathrm{mg} / \mathrm{dl}$, kolesterol $\mathrm{HDL} \leq 25 \mathrm{mg} / \mathrm{dl}$, dan trigliserida $\geq 130 \mathrm{mg} / \mathrm{dl} .{ }^{27}$

Tahap intervensi dilakukan selama 14 hari, keempat kelompok diberikan pakan standar. Kelompok perlakuan P1, P2 dan P3 diintervensi dengan diberikan kombinasi minyak rami dengan minyak wijen. Pembuatan minyak rami dan minyak wijen dihasilkan dari biji rami berwarna coklat dan biji wijen berwarna putih. Metode pembuatan minyak adalah Hydraulic Pressing (prengepresan hidrolik). Uji kandungan asam lemak dan aktivitas antioksidan dari minyak rami dan minyak wijen dilakukan di Laboratorium Penelitian dan Pengujian Terpadu (LPPT) Universitas Gajah Mada Yogyakarta. Analisis antioksidan dilakukan menggunakan metode RSA (Radical Scavenging Activity).

Kelompok perlakuan P1 diberikan pakan standar dan kombinasi minyak rami dengan minyak wijen dosis 1ml/200 gBB. Kelompok perlakuan P2 diberikan pakan standar dan kombinasi minyak rami dengan minyak wijen dosis $2 \mathrm{ml} / 200 \mathrm{gBB}$. Kelompok perlakuan $\mathrm{P} 3$ diberikan pakan standar dan kombinasi minyak rami dengan minyak wijen dengan dosis $3 \mathrm{ml} / 200 \mathrm{gBB}$.

Penentuan dosis kombinasi minyak rami dengan minyak wijen didasarkan pada penelitian sebelumnya pada tikus yang diberi intervensi minyak wijen dosis $5 \%$ dan $10 \%$ dari total pakan tikus. ${ }^{28}$ penelitian ini menggunakan dosis 5\%, 10\%, dan $15 \%$. Perhitungan dosis 5\% dari total pakan yang diberikan $=5 \% \times 20 \mathrm{~g}=1 \mathrm{~g}=1 \mathrm{ml} /$ hari. Perhitungan dosis $10 \%$ dari total pakan yang diberikan $=10 \% \times 20 \mathrm{~g}=2 \mathrm{~g}=$ $2 \mathrm{ml} /$ hari. Perhitungan dosis $5 \%$ dari total pakan yang diberikan $=15 \%$ × $20 \mathrm{~g}=3 \mathrm{~g}=3 \mathrm{ml} / \mathrm{hari}$. Pemberian dosis kombinasi minyak rami dengan minyak wijen yaitu $1 \mathrm{ml} / 200 \mathrm{gBB}$ yang terdiri dari $0,5 \mathrm{ml}$ minyak rami dan $0,5 \mathrm{ml}$ minyak wijen, $2 \mathrm{ml} / 200 \mathrm{gBB}$ terdiri dari $1 \mathrm{ml}$ minyak rami dan $1 \mathrm{ml}$ minyak wijen, dan dosis $3 \mathrm{ml} / 200 \mathrm{gBB}$ terdiri dari $1,5 \mathrm{ml}$ minyak rami dan 1,5 ml minyak wijen.

Pengukuran kolesterol HDL akhir dilakukan setelah pemberian intervensi selama 14 hari. Pengambilan sampel darah untuk analisis kadar kolesterol HDL sebelum dan setelah intervensi yaitu sebelumnya tikus dipuasakan selama 12 jam, setelah itu induksi anestesi dengan penyuntikan ketamin 60 $\mathrm{mg} / \mathrm{kg}$ berat badan. Sampel darah diambil sebanyak 3 $\mathrm{ml}$ melalui opthalmic venous plexus (pada sudut mata). Pemeriksaan kadar kolesterol HDL dengan metode CHOD-PAP dengan kit diasys.

Data yang diperoleh diuji normalitasnya menggunakan uji Shapiro-Wilk. Data berdistribusi normal sehingga untuk mengetahui perbedaaan sebelum dan setelah perlakuan diuji statistik dengan uji paired t-test. Setelah dilakukan uji paired t-test, data kemudian diuji dengan uji one way ANOVA dan uji lanjut dengan Uji Post Hoc LSD (Least Significant Difference) untuk melihat perbedaan antar kelompok atau paling tidak terdapat perbedaan antara dua kelompok perlakuan. ${ }^{29}$

\section{HASIL PENELITIAN \\ Karakteristik Sampel}

Sampel pada penelitian ini adalah 24 ekor tikus Sprague dawley jantan dislipidemia 6-8 minggu dengan berat badan 150-200 gram. Sampel dipelihara dalam kandang individu dengan suhu ruangan berkisar antara $28-32^{\circ} \mathrm{C}$ dengan siklus pencahayaan 12 jam. Kandang setiap hari dibersihkan dan pemeliharaan. Pada saat perlakuan tidak terjadi drop out pada masing-masing kelompok sehingga sampel tetap berjumlah 24 ekor tikus.

\section{Kandungan Asam Lemak dan Aktivitas Antioksidan}

Kandungan asam lemak dan aktivitas antioksidan pada minyak rami dan minyak wijen dapat dilihat pada tabel 1 . Metode analisis kandungan asam lemak pada minyak rami dan minyak wijen menggunakan metode kromatografi gas. 
Tabel 1. Kandungan asam lemak dan aktivitas antioksidan minyak rami dan minyak wijen dari hasil uji Laboratorium Penelitian dan Pengujian Terpadu Universitas Gajah Mada Yogyakarta

\begin{tabular}{|c|c|c|c|c|}
\hline \multirow{2}{*}{ No } & \multirow{2}{*}{ Hasil Analisis } & \multirow{2}{*}{ Satuan } & \multicolumn{2}{|c|}{ Kode Sampel } \\
\hline & & & Minyak Rami & Minyak Wijen \\
\hline 1. & Methyl Palmitolelate & $\%$ & 4,72 & 9,94 \\
\hline 2. & Lenolelaidic Acid Methyl Ester (Omega 6) & $\%$ & 26,53 & 83,94 \\
\hline 3. & Methyl Lenoleate (Omega 6) & $\%$ & 67,51 & 5,05 \\
\hline 4. & Methyl Aracehidate & $\%$ & 0,28 & 0,39 \\
\hline 5. & Methyl Cis-11-eicocenoate (Omega 9) & $\%$ & 0,22 & - \\
\hline 6. & $\begin{array}{l}\text { Cis-11 -14 -eicosadienoic Acid Methyl Ester } \\
\text { (omega 6) }\end{array}$ & $\%$ & - & 0,19 \\
\hline 7. & Methyl Docosanoate & $\%$ & - & 0,41 \\
\hline 8. & $\begin{array}{l}\text { Methyl Cis-5-8-11-14-eicosatetraenoic } \\
\text { (Omega 3) }\end{array}$ & $\%$ & 0,1 & - \\
\hline 9. & $\begin{array}{l}\text { Methyl Cis- 5-8-11-14-17 -Eicosapentaenoate } \\
\text { (Omega 3) }\end{array}$ & $\%$ & 0,14 & - \\
\hline 10. & Methyl Nervonate (Omega 9) & $\%$ & 0,34 & - \\
\hline 11. & Antioksidan & $\mathrm{mg} / \mathrm{mL}$ & 8,56 & 14,03 \\
\hline
\end{tabular}

Berdasarkan tabel 1 terbukti bahwa kedua minyak memiliki aktivitas antioksidan dimana aktivitas antioksidan minyak wijen $(14,03 \mathrm{mg} / \mathrm{ml})$ lebih tinggi dibandingkan minyak rami $(8,56 \mathrm{mg} / \mathrm{ml})$. Sedangkan kandungan asam lemak paling tinggi pada minyak rami yaitu Methyl Lenoleate (omega 6) dan pada minyak wijen kandungan paling tinggi adalah kandungan Lenolelaidic Acid Methyl Ester (omega 6).

\section{Analisis Kadar Kolesterol HDL pada Tikus Sprague dawley}

Hasil rerata kadar kolesterol HDL sebelum dan setelah pemberian kombinasi minyak rami dengan minyak wijen dapat dilihat pada tabel 2 . Pemeriksaan kolesterol HDL sebelum intervensi atau pada saat kondisi dislipidemia, tikus dikatakan dislipidemia salah satunya ditandai dengan menurunnya kadar HDL yaitu $\leq 25 \mathrm{mg} / \mathrm{dl} .{ }^{27}$

Tabel 2. Hasil analisis kadar kolesterol HDL darah

\begin{tabular}{|c|c|c|c|c|c|c|}
\hline \multirow[b]{2}{*}{ Kelompok } & \multirow[b]{2}{*}{$\mathrm{n}$} & \multicolumn{2}{|c|}{ Rerata } & \multirow[b]{2}{*}{$\begin{array}{c}\Delta \\
(\mathrm{mg} / \mathrm{dL} \pm \mathrm{SD})\end{array}$} & \multirow[b]{2}{*}{$\Delta \%$} & \multirow[b]{2}{*}{$p^{b}$} \\
\hline & & $\begin{array}{c}\text { Sebelum } \\
(\mathrm{mg} / \mathrm{dL} \pm \mathrm{SD})\end{array}$ & $\begin{array}{c}\text { Setelah } \\
(\mathrm{mg} / \mathrm{dL} \pm \mathrm{SD})\end{array}$ & & & \\
\hline $\mathrm{K}$ & 6 & $25,72 \pm 1,60^{\mathrm{a}}$ & $24,85 \pm 1,68^{\mathrm{a}}$ & $-0,87 \pm 0,08^{\mathrm{a}}$ & $-1,43$ & 0,003* \\
\hline $\mathrm{P} 1$ & 6 & $25,14 \pm 0,71^{\mathrm{a}}$ & $36,35 \pm 2,30^{\mathrm{a}}$ & $11,21 \pm 1,59^{a}$ & 18,49 & $0,000 *$ \\
\hline $\mathrm{P} 2$ & 6 & $25,72 \pm 1,60^{\mathrm{a}}$ & $43,43 \pm 1,50^{\mathrm{a}}$ & $17,71 \pm 0,10^{\mathrm{a}}$ & 29,21 & 0,000* \\
\hline $\mathrm{P} 3$ & 6 & $24,57 \pm 1,99^{a}$ & $55,40 \pm 1,30^{\mathrm{a}}$ & $30,83 \pm 0,69^{a}$ & 50,85 & $0,000 *$ \\
\hline$p^{a}$ & & $\mathbf{0 , 5 3}$ & 0,000* & 0,000* & & \\
\hline
\end{tabular}

\section{Keterangan:}

$\mathrm{K}$ : Kelompok kontrol (diberi pakan tinggi lemak selama 14 hari sebelum intervensi, saat intervensi hanya diberikan pakan standar); P1 : Kelompok perlakuan 1 (diberi intervensi kombinasi minyak rami dengan minyak wijen dengan dosis $1 \mathrm{ml} / 200$ gBB tikus); P2 : Kelompok perlakuan 2 (diberi intervensi kombinasi minyak rami dengan minyak wijen dengan dosis 2ml/200 gBB tikus); P3 : Kelompok perlakuan 3 (diberi intervensi kombinasi minyak rami dengan minyak wijen dengan dosis $3 \mathrm{ml} / 200 \mathrm{gBB}$ tikus).

a : one way ANOVA

${ }^{\mathrm{b}}$ : paired sample t-test

*: berbeda bermakna

Hasil uji analisis paired sample t-test pada tabel 2, terdapat perbedaan bermakna $(p<0,05)$ kadar kolesterol HDL sebelum dan setelah intervensi pada semua kelompok, baik kelompok kontrol maupun kelompok perlakuan P1, P2, dan P3. Kelompok kontrol mengalami penurunan $1,43 \%$ dengan $(p=0,003)$ dan rerata kadar kolesterol HDL sebelum dan setelah intervensi meskipun penurunannya hanya sedikit dari $25,72 \pm 1,60$ menjadi $24,85 \pm 1,68$, tetapi secara stastistik sudah dikatakan bermakna. Peningkatan kadar kolesterol HDL secara bermakna $(p<0,05)$ terjadi pada kelompok $\mathrm{P} 1, \mathrm{P} 2$ dan $\mathrm{P} 3$ berturut-turut yaitu sebesar $18,49 \%, 29,21 \%$, dan $50,85 \%$. Hal ini menunjukkan bahwa pemberian intervensi kombinasi minyak rami dengan minyak wijen dengan dosis bertingkat dapat meningkatkan kadar kolesterol HDL serum pada sampel. Rerata peningkatan kadar kolesterol HDL paling tinggi yaitu pada kelompok P3 yang diberikan kombinasi minyak rami dengan minyak wijen dosis $3 \mathrm{ml} / 200 \mathrm{gBB}$ yaitu sebesar 30,83 mg/dL. 
Dilanjutkan dengan uji one way ANOVA pada kelompok sebelum intervensi diperoleh kadar kolesterol HDL dengan nilai signifikasi sebesar 0,53 ( $p>0,05)$ yang menunjukan tidak terdapat perbedaan antar kelompok sebelum intervensi. Hasil uji one way ANOVA setelah intervensi menunjukkan bahwa kadar kolesterol HDL antar kelompok terdapat perbedaan yang bermakna $(p=0,000)$. Hasil uji lanjutan post hoc $L S D$ menunjukkan tidak terdapat perbedaan yang bermakna sebelum perlakuan pada kelompok (K vs $\mathrm{P} 1)$, (K vs $\mathrm{P} 2)$, (K vs P3), (P1 vs P2), (P1 vs P3), (P2 vs P3) dengan $(p>0,05)$. Terdapat perbedaan bermakna setelah perlakuan antara semua kelompok yaitu kelompok kontrol, kelompok perlakuan P1, P2, P3 $(p<0,05)$. Pada delta/perubahan HDL memiliki perbedaan bermakna pada (K vs $\mathrm{P} 1$ ), (K vs $\mathrm{P} 2$ ), (K vs $\mathrm{P} 3),(\mathrm{P} 1$ vs $\mathrm{P} 2),(\mathrm{P} 1$ vs $\mathrm{P} 3),(\mathrm{P} 2$ vs $\mathrm{P} 3)$ dengan $(p<0,05)$.

\section{PEMBAHASAN}

\section{Kandungan Asam Lemak dan Aktivitas Antioksidan}

Uji kandungan gizi minyak rami dan minyak wijen sudah pernah dilakukan pada penelitian sebelumnya. Penelitian kali ini hanya melakukan uji kandungan asam lemak dan aktivitas antioksidan pada minyak rami dan minyak wijen. Penelitian Guimaraes et, al didapatkan komposisi minyak rami yaitu asam $\alpha$-linolenat $39,90 \%$, asam oleat $17,97 \%$, dan asam linoleat $12,25 \%$. Minyak wijen mengandung asam oleat $28,6 \%$, asam linoleat $28,4 \%$ dan asam laurat $14,6 \% .{ }^{30}$ Penelitian lain ditemukan kandungan asam lemak minyak rami, asam linolenat $57 \%$, asam oleat $18 \%$, asam linoleat $16 \%$ dan lemak jenuh $9 \% .^{15}$

Hasil dari uji kandungan asam lemak pada tabel 1 yaitu kandungan asam lemak tertinggi pada minyak rami yaitu Methyl Lenoleate $67,51 \%$ dan pada minyak wijen kandungan paling tinggi adalah kandungan Lenolelaidic Acid Methyl Ester 83,94\%. Kandungan asam lemak minyak rami dan minyak wijen pada penelitian ini berbeda dengan penelitian sebelumnya. Hal ini dapat dipengaruhi oleh beberapa faktor yaitu kondisi lingkungan seperti suhu saat proses pertumbuhan tanaman, penggunaan pupuk, pemanasan dalam proses pembuatan minyak, cahaya pada saat penyimpanan. ${ }^{13,31}$ Kandungan minyak yang berasal dari biji dapat dipengaruhi oleh faktor agronomi lamanya penyinaran dan lama penanaman. Biji yang diambil saat berkembang atau dipanen lebih awal menghasilkan kandungan minyak yang lebih tinggi daripada yang dipanen lebih lama. Penggunaan pupuk nitrogen yang banyak juga dapat mengurangi kandungan minyak dari biji wijen. ${ }^{32}$

Suhu rendah saat proses pematangan rami dapat meningkatkan akumulasi asam lemak khususnya $\alpha$-linolenat. Penelitian lain yang membahas tanaman biji yang memiliki kandungan $\alpha-$ linolenat menunjukkan bahwa suhu yang rendah dan curah hujan yang tinggi selama proses pertumbuhan dapat meningkatkan produksi asam lemak. Hal ini juga sama dengan biji wijen, pada penelitian lain yang membahas tentang tanaman biji yang mengandung minyak, menjaga suhu rendah selama pematangan biji dapat meningkatkan jumlah asam lemak dalam minyak. ${ }^{33}$

Penelitian ini menggunakan suhu $75^{\circ} \mathrm{C}$ selama 1 jam pada proses pemanasan biji rami dan biji wijen. Sebuah penelitian menunjukkan bahwa komposisi lemak tidak berubah pada biji wijen yang dipanaskan dengan suhu di bawah $200^{\circ} \mathrm{C}$ selama 30 menit. ${ }^{34}$ Penelitian biji rami yang dipanggang dengan suhu tinggi lebih $150^{\circ} \mathrm{C}$ mengalami penurunan kandungan PUFA pada minyak rami. Sehingga dapat dipastikan komposisi asam lemak PUFA yang terkandung pada minyak rami dan minyak wijen pada penelitian ini tidak berkurang. ${ }^{35}$

Hasil analisis aktivitas antioksidan pada minyak rami dan minyak wijen adalah $8,56 \mathrm{mg} / \mathrm{ml}$ dan $14,03 \mathrm{mg} / \mathrm{ml}$. Minyak rami dan minyak wijen memiliki efek dalam penangkapan radikal bebas yang dilihat dari hasil pengukuran aktivitas antioksidan, namun dalam penelitian ini minyak wijen mempunyai efek yang lebih besar dalam menangkap radikal bebas. Analisis antioksidan dilakukan menggunakan metode RSA (Radical Scavenging Activity). Aktivitas antioksidan dari minyak rami berasal dari omega $3(\alpha-$ linolenat, eicosapentaenoic), polifenol, dan vitamin $\mathrm{E}$ seperti $\alpha$ tokoferol, $\beta, \gamma$ dan $\delta$ serta kandungan plastochromanol-8, dan flavonoid. ${ }^{15,36,37}$ Kandungan antioksidan pada minyak wijen berasal dari $\gamma$ tokoferol dan antioksidan endogen seperti sesamol, sesamolin, dan sesamin. ${ }^{19,21,22}$

\section{Pemberian Pakan Tinggi Kolesterol terhadap Kadar Kolesterol HDL Tikus Sprague dawley}

Pada penelitian ini untuk menginduksi tikus dislipidemia digunakan pakan tinggi kolesterol yang berupa lemak babi $10 \%$ ( $2 \mathrm{ml} / \mathrm{hari}$ ), asam kolat sebanyak $2 \%(0,04 \mathrm{ml} / \mathrm{hari})$ dan air sebanyak $2 \mathrm{ml}$ selama 14 hari. Pemberian lemak babi karena tingginya kandungan asam lemak jenuh dan kolesterol yang tinggi. Pemberian lemak babi juga dapat meningkatkan berat badan pada tikus. Pemberian asam kolat dapat meningkatkan kadar kolesterol sebesar $360 \%$ pada tikus yang akan dibuat hiperkolesterolemia. ${ }^{18}$

Hasil penelitian menunjukkan rerata kadar kolesterol HDL setelah pemberian pakan tinggi kolesterol pada semua kelompok tergolong rendah yaitu $\mathrm{HDL} \leq 25 \mathrm{mg} / \mathrm{dl}$. Hasil analisis beda rerata menunjukkan bahwa terdapat perbedaan secara bermakna antar kelompok sebelum dan setelah 
perlakuan. Terdapat penurunan kadar HDL pada kelompok kontrol dapat disebabkan karena asupan pakan standar yang mengandung lemak 3-7\% dan protein $15 \%$.

Asam lemak jenuh dan kolesterol dapat mempengaruhi profil serum lipoprotein, kenaikan kadar kolesterol, tidak hanya menaikkan kadar kolesterol LDL tetapi juga menurunkan kadar kolesterol HDL. Asam lemak jenuh dan kolesterol juga bersifat aterogenik (memicu penyempitan, penebalan, dan pengerasan dinding pembuluh darah) serta menginhibisi aktivitas enzim pada metabolisme lipid (fatty acid desaturase elongase dan lecithin cholesterol acyltransferase/LCAT). Enzim ini terlibat dalam metabollisme kolesterol HDL khususnya pada pengangkutan balik kolesterol dari jaringan ke hati. Sedangkan fungsi kolesterol HDL itu sendiri mengangkut kembali kelebihan kolesterol dijaringan untuk dibawa ke hati dan diubah kembali menjadi VLDL. Sistem LCAT berperan dalam proses pengeluaran kolesterol tidak teresterifikasi yang berlebihan dari lipoprotein dan jaringan menuju hati. Asam lemak jenuh dalam jumlah tinggi dapat menghambat kerja enzim LCAT dalam proses pengeluaran kolesterol dari jaringan dan lipoprotein, sehingga pembentukan HDL terhambat mengakibatkan kadar kolesterol HDL dalam darah menurun. ${ }^{38,39}$

\section{Pengaruh Pemberian Kombinasi Minyak Rami Dengan Minyak Wijen terhadap Kadar Kolesterol HDL}

Rerata kadar kolesterol HDL setelah pemberian pakan tinggi kolesterol (lemak babi) pada semua kelompok tergolong rendah yaitu HDL $\leq 25$ $\mathrm{mg} / \mathrm{dl}$. Hal ini dikarenakan lemak babi mengandung tinggi asam lemak jenuh dan kolesterol. Setelah terjadi penurunan kadar kolesterol HDL pada sampel kemudian sampel diberi intervensi dengan pemberian kombinasi minyak rami dengan minyak wijen dengan dosis bertingkat $1 \mathrm{ml}, 2 \mathrm{ml}$, dan $3 \mathrm{ml}$ untuk melihat peningkatkan kadar kolesterol HDL tikus.

Pemberian kombinasi minyak rami dan minyak wijen selama 14 hari pada tikus dislipidemia terbukti dapat meningkatkan kadar kolesterol HDL karena senyawa-senyawa yang terkandung dalam kedua minyak yang saling menguntungkan satu sama lain. Pada penelitian ini menunjukkan adanya perbedaan yang bermakna sebelum dan setelah intervensi pada kelompok perlakuan. Kadar kolesterol HDL setelah intervensi pada kelompok perlakuan 1 (dosis 1ml/200grBB), kelompok perlakuan 2 (dosis $2 \mathrm{ml} / 200 \mathrm{grBB})$, dan kelompok perlakuan 3 (dosis $3 \mathrm{ml} / 200 \mathrm{grBB}$ ) secara berturutturut memiliki rerata peningkatan sebagai berikut $11,21 \mathrm{mg} / \mathrm{dl}, \quad 17,71 \mathrm{mg} / \mathrm{dl}$, dan $30,83 \mathrm{mg} / \mathrm{dl}$. Peningkatan paling tinggi pada kelompok P3 dengan dosis kombinasi $3 \mathrm{ml} / 200 \mathrm{gBB}$ dengan rerata kadar HDL setelah perlakuan $55,40 \mathrm{mg} / \mathrm{dl}$.

Hasil penelitian ini sesuai dengan penelitian sebelumnya bahwa minyak rami dan minyak wijen dapat meningkatkan kadar kolesterol HDL secara signifikan. Penelitian pemberian minyak rami dengan dosis 20,30 , dan $40 \mathrm{gm} / \mathrm{kg}$ pada tikus, didapatkan hasil bahwa dosis $40 \mathrm{gm} / \mathrm{kg}$ paling tinggi dalam meningkatkan HDL dengan rerata $44,2 \mathrm{mg} / \mathrm{dl} .{ }^{17}$ Penelitian pemberian minyak wijen dosis $5 \%$ dan $10 \%$ pada tikus hiperlipidemia juga dapat meninggikan kadar HDL secara signifikan, namun minyak wijen dengan dosis 5\% lebih efektif meningkatkan HDL dibandingkan dosis $10 \%$. Rerata kadar kolesterol HDL pada tikus yang diberi minyak wijen dosis $5 \%$ yaitu $38,01 \mathrm{mg} / \mathrm{dl}^{28}$ Jika dibandingkan penelitian sebelumnya yang hanya diberikan minyak rami saja atau minyak wijen saja, penelitian pemberian kombinasi minyak rami dengan minyak wijen dosis $3 \mathrm{ml} / 200 \mathrm{grBB}$ terbukti lebih efektif dalam meningkatkan kadar kolesterol HDL.

Kolesterol HDL meningkat setelah diberikan kombinasi minyak rami dengan minyak wijen karena adanya senyawa-senyawa dalam minyak rami dan minyak yaitu kandungan PUFA (omega 3 dan omega 6). Selain itu juga kandungan sesamin dan sesamol yang berperan sebagai antioksidan endogen pada minyak wijen. Kandungan omega 3 yang ditemukan pada minyak rami berupa methyl Cis-5-8-11-14eicosatetraenoic dan methyl Cis-5-8-11-14-17eicosapentaenoate, tetapi pada minyak wijen tidak ditemukan. Kandungan omega 6 ditemukan di kedua sampel minyak yaitu dalam bentuk methyl lenoleate, lenolelaidic acid methyl ester, dan Cis-11-14eicosadienoic acid methyl ester. Konsumsi PUFA (omega 3 dan omega 6) dan MUFA berhubungan dengan peningkatan konsentrasi kolesterol HDL sampai 5\% dan penurunan TG sebesar 10-15\%. Minyak rami dan minyak wijen kaya akan asam linolenat, asam linoleat, dan asam oleat yang memiliki efek antioksidan dan hipolipidemik. Asam linolenat dapat mengurangi akumulasi lipid di hati dengan merangsang $\beta$-oksidasi dan menekan sintesis asam lemak. ${ }^{39,40,41}$

Kandungan antioksidan pada minyak wijen berasal dari antioksidan endogen seperti sesamol, sesamolin, dan sesamin. Mekanisme antioksidan dari minyak rami dan minyak wijen yang dapat meningkatkan kolesterol HDL dalam darah. Antioksidan dapat meningkatkan kadar kolesterol HDL dengan cara meningkatkan mRNA Apolipoprotein A (Apo A) di hati yang berperan untuk menginisiasi sintesis Apo A. Apolipoprotein A memainkan peran dalam metabolisme kolesterol HDL, sebagai kofaktor dalam proses esterifikasi kolesterol dalam aliran darah oleh LCAT, kemudian 
kembali ke hati untuk ekskresi asam empedu atau redistribusi ke jaringan lain. Peningkatan Apo A disertai dengan peningkatan kadar kolesterol HDL, menekan perbanyakan LDL sehingga tidak terjadi LDL oksidasi. Apolipoprotein A diduga menjadi penanda pertahanan antiaterogenik. Peningkatan Apo A mungkin dapat membantu untuk mengurangi kejadian hiperkolesterolemia dan penyakit kardiovaskular. ${ }^{30,42}$

Efek hipolipidemia pada sesamin terjadi melalui penghambatan enzim-enzim yang berperan untuk sintesa asam lemak antara lain glucose-6phophate dehydrogenase, ATPcitratelyase dan pyruvate kinase. sesamin akan meningkatkan enzimenzim yang berperan untuk proses oksidasi asam lemak, antara lain acyl-CoA oxidase,carnitine palmitoyltransferase, 3-hydroxyacyl-CoA dehydrogenase dan 3-ketoacyl-CoA thiolase.

Tikus wistar yang diberikan diet sesamin 0,5 $\%$ selama 4 minggu melalui sonde dapat menurunkan absorbsi kolesterol limfatik dan meningkatkan ekskresi steroid netral antara lain coprostanol dan kolesterol pada feses. Penurunan absorbsi kolesterol diduga akibat penurunan solubilitas micellar kolesterol. Penurunan kolesterol juga diakibatkan penurunan aktifitas $H M G-C o A$ reductase oleh sesamin, sedangkan peningkatan ekskresi kolesterol ini juga dikarenakan semakin meningkatnya produksi kolesterol HDL, sehingga terjadi penurunan kolesterol LDL, VLDL dan trigliserida. ${ }^{43-45}$

\section{KETERBATASAN PENELITIAN}

Keterbatasan penelitian ini adalah tidak dilakukan analisis kandungan antioksidan, kandungan asam linolenat (omega 3),asam linoleat (omega 6) dan sesamin secara spesifik pada minyak rami dan minyak wijen.

\section{SIMPULAN}

Rerata kadar kolesterol HDL setelah pemberian pakan tinggi kolesterol (lemak babi) pada semua kelompok tergolong rendah yaitu HDL $\leq 25$ $\mathrm{mg} / \mathrm{dl}$. Pemberian kombinasi minyak rami dengan minyak wijen pada tikus Sprague dawley dislipidemia selama 14 hari dengan dosis bertingkat yaitu $1 \mathrm{ml}, 2 \mathrm{ml}$, dan $3 \mathrm{ml}$ secara bermakna dapat meningkatkan kadar kolesterol HDL serum tikus. Peningkatan kadar kolesterol HDL paling tinggi pada kelompok perlakuan 3 dengan dosis $3 \mathrm{ml} / 200 \mathrm{gBB}$.

\section{SARAN}

Penelitian lebih lanjut dibutuhkan pada subjek manusia penderita dislipidemia karena hasil penelitian menunjukkan hasil yang signifikan kombinasi minyak rami dengan minyak wijen dalam meningkatkan kadar kolesterol HDL.

\section{DAFTAR PUSTAKA}

1. Goldstein, Joseph L, Michael SB. Artericlerosis, Thrombosis and Vascular Biology. 2009;29:431 438.

2. Adam I. Peran Kolesterol HDL Dalam Mencegah Penyakit Arteri Koroner pada Penderita Diabetes. Artikel Penyakit Dalam. Universitas Hasanudin, Makasar. 2011.

3. Ekananda N. Bay Leaf in Dyslipidemia Therapy. 2015;4:64-69.

4. Perkumpulan Endokrinologi Indonesia (PERKENI). Konsensus Pengelolaan Dislipidemia Di Indonesia. 1st ed. Jakarta: Pusat Penerbitan Ilmu Penyakit Dalam FKUI. 2012.

5. Carroll MD, Kit BK, Lacher DA. Total and highdensity lipoprotein cholesterol in adults: National Health and Nutrition Examination Survey. NCHS Data Brief. 2010;92:1-8.

6. Nichols M, Townsend N, Luengo-Fernandez R, et al. European Cardiovascular Disease Statistics 2012. European Heart Network, Brussels, European Society of Cardiology, Sohia Antipolis. 2012.

7. Hasil Riset Kesehatan Dasar (RISKESDAS). Prevalensi Dislipidemia. 2013.

8. Maria E. Perbandingan profil lipid dan perkembangan lesi aterosklerosis pada tikus wistar yang diberi diet perasan pare dengan diet perasan pare dan statin. Tesis program biomiedik program paska sarjana. Semarang: Universitas Diponegoro. 2005.

9. Kathleen MB, Mayes PA. Sintesis, Pengangkutan, dan Ekskresi Kolesterol. Dalam: Murray RK, Granner DK, Rodwell VW, editor. Biokimia harper 27th ed. Jakarta: EGC. 2006.

10. LIPI. Kolesterol. UPT-Balai Informasi Teknologi LIPI. Pangan dan Kesehatan. 2009:1-4.

11. Karyadi E. Kiat mengatasi diabetes, hiperkolesterolemia, stroke. Jakarta: PT. Intisari Mediatama. 2006.

12. Fernandez I, Pallaro AN, Slobodianik NH. Comparative study between two different sources of n-3 polyunsaturated fatty acids and it effect on thymus and lipid profile in rats. Archivos Latinoamericanos de Nutrición. 2007;57:146-154.

13. Morris DH. Flax-a Health and Nutrition Primer, Flax Council of Canada. 4th Ed. Canada. Winnipeg MB. 2007; p. 6 - 9, $54-5$.

14. Biswas P, Dhar, S Ghosh. Antihyperlipidemic effect of sesame (Sesamum indicum L.) protein isolate in rats fed a normal and high cholesterol diet. Journal of Food Science. 2010;75(9):274-279.

15. Prasad K. Flaxseed: a source of hypocholesterolemic and antiatherogenic agents. Drug News Perspect. 2000; 13: 99-102.

16. Zhang BS, Yang SF, Fu SG, Yang HC, Sun HL, Chen YC. Effects of dietary flaxseed oil on cholesterol metabolism of hamsters. Food Chemistry. 2009; 114:1450-1455.

17. Sayeda EL, El-Sahar GE, Abor MM, Abed ER. Study on the biological effect of use flaxseed oil as a source of fat on the biomarkers of experimental rats. Journal of American Science. 2014;10(3);116-123 
18. Anilakumar KR, Pal A, Khanum F, Bawa AS Nutritional, Medicinal and Industrial Uses of Sesame (Sesamum indicum L.) Seeds - An Overview. Agriculturae Conspectus Scientificus. 2010.

19. Sedigheh A, Mahmoud R, Somayeh N, Esfndiar H, Amirhossein S. Antihyperlipidemic Effects of Sesamum indicum L. In Rabbits Fed a High-Fat Diet. Hindawi Publishing Corporation The ScientificWorld Journal. 2013:5.

20. Fukuda Y, Nagata M, Osawa T, Namiki M. Chemical aspects of the antioxidants activity of roasted sesame seed oil, and the effect of using the oilfor frying. Agric. Biol. Chem.1986;50:57-62.

21. Małgorzata A, Anna B, Kamil K, Anna K. Sesame and linseeds oil. Plant Lipids Science, Technology. Nutritional Value and Benefits to Human Health. 2015: 43-63

22. Hamed S, Elwafa G. Enhancement of oxidation stability of flax seed oil by blending with stable vegetable oil. Journal of Applied Sciences Research. 2012;8(10):5039-5048.

23. Goutam T, Analava M, Kunal P, Derick R. Effect Of Flaxseed Gum On Reduction Of Blood Glucose \& Cholesterol In Type 2 Diabetic Patients. International Journal of Food Sciences and Nutrition. 2009;60(s6):126-136.

24. World Health Organization. Research Guidelines for Evaluation The Safety and Efficiacy of Herbal Medicine In: Geneva; 2000

25. Fox JG, Cohen BJ, Loew FM. Laboratory animal medicine. Academic Press Inc. 1984:91-120.

26. MN Syadza, Isnawati M. Pengaruh Pemberian Jus Pare (Momordica charantia Linn.) dan Jus Jeruk Nipis (Citrus aurantifolia) Terhadap Peningkatan Kadar Kolesterol HDL (High Density Lipoprotein) Tikus Sprague dawley Dislipidemia. J Nutr Coll. 2014;3(4).

27. Dewi R. Pemberian Growth Hormone Memperbaiki Profil Lipid Dan Menurunkan Kadar MDA (Malondyaldehide) Pada Tikus Jantan Yang Dislipidemia. 2011.

28. Taha MN, Abed EA, Mandour, Mahdy K, Mohamed, Rasha TE.Effect of Sesame Oil on Serum and Liver Lipid Profile in Hyperlipidemic Rats. Alexandria Journal of Veterinary Sciences, 2014;43:18-25.

29. Dahlan MS. Statistik untuk Kedokteran dan Kesehatan. Jakarta: Salemba Medika; 2008.

30. Guimares R, Macedo M, Munhoz C, Filiu W, Viana L, Nozaki V, Hiane P. Sesame and flaxseed oil: nutritional quality and effects on serum lipids and glucose in rats. Food Science and Technology, Campinas. 2013;33(1):209-217.

31. Nykter M, Kymalainen HR.. Qualtiy Characteristics Of Edible Linseed Oil. Agricultural and Food Science. 2006;15:402-413.

32. Hegde DM. Handbook of herbs and spices - sesame. Woodhead Publishing Limited. 2012: 169-184.

33. Savoire R, Lazouk M, Hecke E, Roulan R, Tavernier R, Guillot X, Rhazi L, Petit E, Mesnard F, Thimasset B. Environmental and varietal impact on linseed composition and on oil unidirectional expresion process. OCL Journal. 2015;22(6).
34. Hwang L. Sesame Oil. Bailey's Industrial Oil and Fat Products. Sixth Edition. 2005.

35. Moknstjou R, Hajimahmoodi M, Toliyat T, Moghaddam G, Sadeghpour O, Esfahani M, et, al .Effect of roasting on fatty acid profile of brown and yellow varieties of Flaxseed (Linum usitatissimum $L$ ). 2015;14(1):117-123

36. NYU Langone Medical Center. Flaxseed Oil. 2013.

37. Peterson J, Dwyer J, Adlercreutz H, Scalbert A, Jacques P, Mullough ML. Dietary lignans: physiology and potential for cardiovascular disease risk reduction. Nutrition Reviews. 2010;68(10):571603.

38. Mayes PA. Pengangkutan dan Penyimpanan Lipid. Dalam: Bani AP, Sikumbang MN, editor. Biokimia Harper. Edisi 25. Alih bahasa: Hartono A. Jakarta: EGC. 2003. 254-270.

39. Mensink RP, Zock PL, Kester ADM, Katan MB. Effects of dietary fatty acids and carbohydrates on the ratio of serum total to HDL cholesterol and on serum lipids and apolipoproteins: a meta-analysis of 60 controlled trials. Am j Clin Nutr 2003;77(11):46-55.

40. Denmacker P N, Reijnen IG, Katan MB, Stuyt PM, Stalenhoef AF. Increased removal of remnants of triglyceride-rich lipoproteins on a diet rich in polyunsaturated fatty acids. Eur J Clin Invest 1991;21:197-203.

41. Zheng C, Khoo C, Furtado J, Ikewaki K, Sacks FM. Dietary monounsaturated fat activates metabolic pathways for triglyceride-rich lipoproteins that involve apolipoproteins E and C-III. Am j Clin Nutr 2008;99:272-81.

42. Hussein S, Yakout A, El-Senosi M, Ragab MF, Hammad. Beneficial Effect Of Flaxseed Oil On Lipid Metabolism In High Cholesterol Diet Fed Rats. Benha Veterinary Medical Journal. 2014;27(2):290301.

43. Fatmawati NK. Efek Proteksi Kombinasi Minyak Wijen Dengan A-Tocopherol Terhadap Steatosis Melalui Penghambatan Stres Oksidatif Pada Tikus Hiperkolesterolemia. Jurnal Teknologi Pertanian, 2006;1(2):60-67.

44. Lee SY, Son DJ, Lee YK, Lee JW, Lee HJ, Yun YW, Ha TY, Hong JT. Inhibitory Effect of Sesaminol Glucosides on Lipopolysaccharide-induced $\mathrm{Nf}-\mathrm{Kb}$ Activation and Target Gene Expression in Cultured Rat Astrocytes. Neurosci. Res. 2006;56:204-212.

45. Jillian S. Hormonal Enzyme Systems and Botanical Agent. Medicines from the Earth. Offical Proceedings. 2010;4(7):134-137. 